\title{
The Rise of the Platforms: Business Model Innovation Perspectives
}

\author{
Rimantas Gatautis \\ Kaunas University of Technology \\ K. Donelaicio st. 73, LT-44029, Kaunas, Lithuania \\ E-mail.rimantas.gatautis@ktu.lt
}

cross $^{\text {ref }}$ http://dx.doi.org/10.5755/j01.ee.28.5.19579

\begin{abstract}
Platforms are increasingly playing a more important role in companies' activities. Even if companies are not developing their platforms, they need to cope with the opportunities brought by the companies. Platforms phenome is gaining more and more attention as companies such as Google, Amazon, Apple, Microsoft, and others are successfully utilizing platforms for business development. Platform phenomenon is considered a new one and various researchers outline the need for more deep studies of platform role and impact on companies, industries, value systems, and economies. This paper explores platform and business model innovation concepts to understand how the platform can contribute to companies' business models innovations. The paper analyses shift from technical to managerial of platform interpretation, characteristics of the platform, business model and business model concepts and platform business model. The platform business models are analysed through business model innovation perspective - what kind of new users are involved in platforms, how platforms can contribute to value proposal development, what benefits platforms brings to companies and how platforms impact companies business model financial aspects. Finally, the reasons why companies fail implement platforms business model are presented as well.
\end{abstract}

Keywords: Platforms, Business Model, Business Model Innovation, Platform Business Model, Innovation.

\section{Introduction}

Digital technologies are actively penetrating different areas of Digital technologies are actively penetrating different areas of business activities, political activities as well as a wide range of social interactions. We observe a tendency where companies increasingly use digital technologies in order to capture consumers' attention and develop long-lasting relations. The main players in this domain, such as Google, Facebook, Amazon, Apple and Microsoft successfully do it. Their success in doing so has to do with their ability to implement a platform business model, which is a technology platform that serves as a key channel for value creation and transfer.

Over the course or the last year we have observed many discussions between practitioners and research regarding platforms. Kenney and Zysman (2016) have proposed a platform economy definition, emphasizing platforms' contribution to the economic development. According them "we are in the midst of a reorganization of our economy in which the platform owners are seemingly developing power that may be even more formidable than was that of the factory owners in the early industrial revolution." A similar approach has been recently put forward by Gartner (2017) claiming that "platforms are new foundations for value creation".

The growing importance of platforms has also been stressed at the World Economic Forum 2016 by outlining the importance of platforms for companies and organisations, naming disruption of economic activities, lower market entrance barriers, and in some cases changes to the logic of value creation, capture and transfer to market (DAVOS, 2016).

According J. Bughin (2016) "platforms redefine value propositions for customers, reshaping the demand side of the market" and companies aiming to apply platforms needs to innovate business model perspective.

As "platforms are no longer restricted to retail or hightech, but are visible across multiple industries (MIT Platform Summit, 2017) the platform phenomenon is attracting more attention from the researchers and studies about platforms, platform business models, platforms impact on economy is gaining attention.

Platforms are penetrating different industries and facilitating cooperartion and value creation between different companies (Accenture, 2016). As a consequence companies needs to understand how to change business models in order sucessfuly compete in the platforms based digital ecosystems. As platforms heavily affect the way how value is creation, companies need sto adjust their business models in order to operate in platforms based global value chains and value systems.

The platform phenomenon started as digital technolgies enabling companies to offer their products and services. However, nowdays platforms are not just selling chanels anymore. Platforms acts as value creation orchestrators enabling cooperation between different market players.

As platform is new phenomenon "the impact of platforms on innovation and competition still needs to be refined (Gawer \& Cusumano, 2012)." The need for better understanding of platforms is crucial as Parker et all (2016) suggest that companies must embrace platform thinking in order to compete in the future, - "practically any industry in which information is an important ingredient is a candidate for the platform revolution". Accenture (2016) indicates that $88 \%$ of the Fortune 500 companies are looking for opportunities to use platforms and actively invest in platforms. Despite, such interest from business side, platform 
use for business model innovations remain relatively unexplored (Altman \& Tripsas, 2015).

Having this is mind, the purpose of the research proposed in this paper is to explore the ways platforms use perspectives in the companies and role platforms can play in business model innovation. Within this context paper aims:

- to analyze platform concep;

- to analyze business model and business model innovation concept;

- to define interdependiencies between these concept in order to elaborate platforms use for business model innovation.

In order to achieve this purpose, the method of systematic analysis of scientific literature will be employed. The systematic analysis will enable to provide overview of differen inconsistent research about platforms and platforms use in business model context and to define interdependencies between the two concept.

\section{The Concept of Platform}

The term 'platform' has been around for years, but researchers and practitioners' attention to the platforms increased in the last decade. Tevari and Sarren suggest that term platform has been used for the last 25 years in the various economic, management, business administration, marketing or other discourses. Earlier, the term platforms were related to technological solutions development. These solutions were oriented to help companies to facilitate various activities. According Schwarz (2015) platforms might define as "digital infrastructure (hardware and/or software) on which different applications can be run, or (by wider definition) allowing for a finite and clearly defined set of uses." That approach suggests a technical interpretation of the platform.

However, with the development of global companies, such as Google, Facebook, Amazon, Apple, and their active role in various fields the term "platform" changed the initial meaning. According Parker at all (2016) platforms are defined as a new business model that uses technology to connect people, organizations, and resources in an interactive ecosystem in which amazing amounts of value can be created and exchanged". As authors notice, the platform business model is dominantly used by leading companies in different regions (see table 1 ).

Platform Business Model Using Companies in Different Regions

\begin{tabular}{|l|l|}
\hline Region & Companies using platform business model \\
\hline North America & $\begin{array}{l}\text { Google, Apple, Microsoft, Amazon, Oracle, } \\
\text { Intel, Microsoft }\end{array}$ \\
\hline Asia & Softbank, Tencent, JB, Alibaba, Baidu \\
\hline Europe & SAP, Spotify \\
\hline
\end{tabular}

The growing attention to platforms is followed by investment in platforms development. According to Accenture (2016) the investment into platforms development are steadily growing in the 2010-2015 period in al regions (see Figure 1).

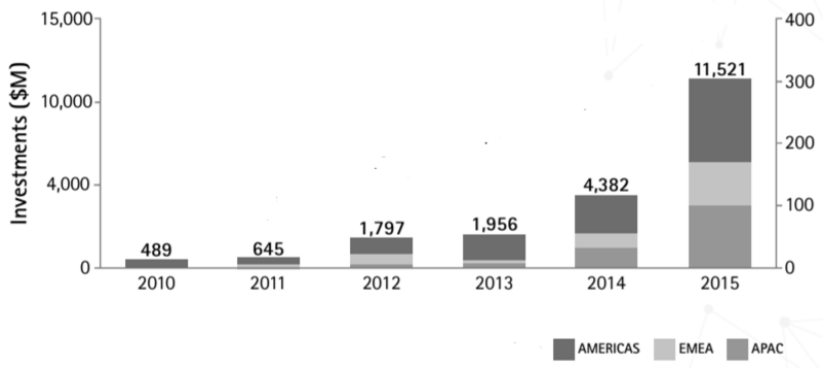

Figure 1. Investment in Digital Platforms 2010-2015 (adapted from Accenture, 2016)

The European Commission (2015) after public consultations define platforms as "an undertaking operating in two (or multi)-sided markets, which uses the Internet to enable interactions between two or more distinct but interdependent groups of users so as to generate value for at least one of the groups. Certain platforms also qualify as intermediary service providers."

J. Kim (2015) suggests three important characteristics, describing platforms:

- Two side market;

- Network effects;

- Ecosystem.

Two-sided market refers to s platforms' ability to act between different types of consumers and ability to match value between them. This approach is widely adopted, i.e., as Google offers information for consumers and ability to reach consumers through advertising for companies, Amazon is offering products for end users and allow producers to use Amazon platform for accessing them.

Network effects refer to increase of value through growing number of users. Network effects are following transactions appearing in two-sided markets and in particularly strengthening indirect effects (Cusumano, 2008), such as learning from those users, the power of a well-known brand and user inertia.

The ecosystem concept was defined by Moore (1996) and refers to "an economic community supported by a foundation of interacting organizations and individualsthe organisms of the business world." Within these context, platforms build economic communities of consumers and/or companies and sustain them through coordination of value provision.

Besides these characteristic Accenture (2016) suggests another important two:

- Distribution Power. Platforms enable scaling, and supply-side platform participants can generate profits even in the "long tale". The scaling cost is minimal (differently from traditional (linear) models).

- Asymmetric Growth and Competition. The platform provides opportunities for the same companies to compete I the same and complementary markets. Companies can use different approaches and resources aiming for successful performance.

These characteristics demonstrate the specific nature of the platform business model and its differences from the classical approach to value creation. From the classical perspective, value is created in liner manner - producers produce good, logistic companies deliver goods, marketing 
activities are used to promote goods and through different retail points goods are delivered to consumers. The platform approach to value creation is different. The platform acts as a value orchestration mechanism organizing value creation in two ways and ensuring continuous value creation (Accenture, 2016).

Besides these characteristics platforms play another important role (Parker et al., 2016), such as:

- Elimination of gatekeepers;

- Creation of community feedback loops;

- Unlocking new sources of value creation;

\section{Business Model and Business Model Innovation Concept}

The business model concept has been studied widely for the last several decades. Many researchers associate business model is with four questions:

- Who? To whom company creates value?

- What? What company is offering to the customers?

- How? How company offers are created?

- What's in it? Financial aspects of company operations - cost and revenues.

This approach was more widely elaborated by Osterwalder and Pigneur (2009), and it has been widely adopted across practitioners. Researchers identify nine key component describing business model:

- Segment - the group of customers' company is approaching;

- Value proposition - usually associated with company products and/or services and helping customers to solve their problems;

- Delivery channels- means the company is using to deliver value to segments. Companies might use physical or digital channels;

- Relationship - describes what type of relations company is seeking to establish with the customers;

- Key resources - what kind of physical, virtual, financial, human or other are required for value creation;

- Key activities - what kind of activities using different resources are required to create value;

- Key partnership - what kind of partners' company needs to create and transfer value;

- Revenues- how company is earning revenues;

- Cost - what are the main cost related to value creation and delivery.

According to the proposed framework companies can easily describe their business model.

The business model concept has been widely studied in various management, economics, strategic management, marketing and other disciplines. It remains perspective research area as new technologies and solutions bring new possibilities for business models implementation.

The related concept, which also tackles business model implementation, is business model innovation. Business model innovation can be defined as "changes in business logic that are new to the firm, yet not necessarily new to the world, and have to result in observable changes in the practices of a BM" (Bouwman et al., 2008)."

The changes which are introduced might be caused by technologies development (such as social media, IoT, big data), the situation in the market (competitive pressure) or even by political decisions (legal regulation). Companies reacting to these decisions need to take appropriate actions in changing their daily operations, and that is reflected in their business model.

As technologies develop rapidly and markets became very dynamic, business model innovation became a necessity for a company to operate in the market. As it was pointed out by BCG (2017), - "in the past 50 years, the average business model lifespan has fallen from about 15 years to less than 5. Business model innovation is thus no longer one of many ways to gain a competitive edge, but it is a necessary core capability to respond to-and capitalize on-a changing world".

The H2020 program funded project ENVISION has been studying business model innovation across SMEs in EU for several years and notes that about 37 percent of European SMEs are involved in business model innovations development. The key factors causing business model innovation between SMEs:

- Price pressure from competitors;

- New customer needs;

- New product development;

- Attempt to minimize cost;

- Focus on product development;

As the results European SMEs business model innovation is expressed through these activities (ENVISION, 2017):

- servitization and service bundling;

- search for new customers and new markets;

- revenue streams adjustment through new pricing decisions;

- engagement with various IT applications, such as social media, big data, etc.

These findings demonstrate that digital technologies play important role in European SMEs business model innovation, and platforms adoption between SMEs should lead to new platform based business models.

According to Foss and Saebi (2016) business model innovation falls under one of the four categories (see Figure 2).

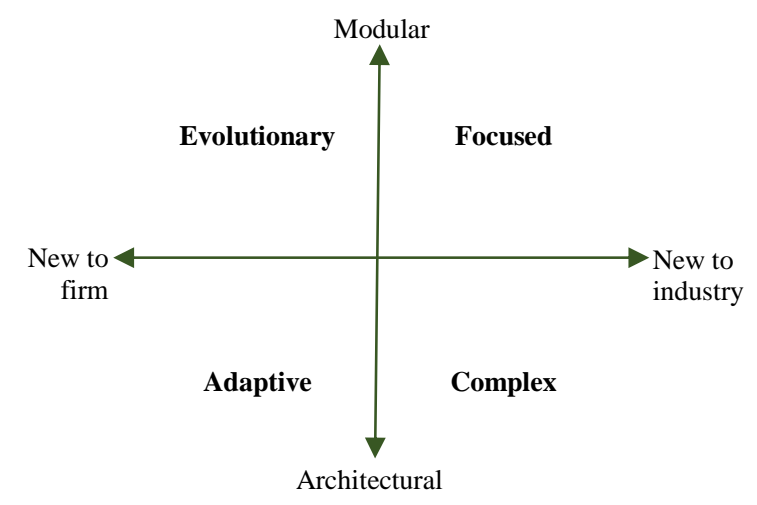

Figure 1. Business model innovation typology (based on Foss \& Saebi, 2016) 
The proposed typology is based on two criteria novelty (as BMI might be novel to firm or to the market) and scope (as BMI might be characterized by architectural and modular changes). According to Foss and Saebi (2016) evolutionary BMI relates to "voluntary and emergent changes" in each component of the business model. Adaptive BMI refers to changes occurring in the whole business model. Focused and complex BMI are characterized by active managerial attempts to implement "modular or architectural changes in the BMI to disrupt market conditions (Foss and Saebi, 2016). "

Although business model innovation is necessary for successful operation in the market there are not many studies addressing barriers to business model innovation. Chesbrough (2010) identified confusion or obstruction - as key barriers to business model innovation. These barriers relate to managers' mindset and managers' resistance, as well as to unwillingness to change to avoid risk.

The business model concept is still underexplored and requires attention from the researchers. As Foss and Saebi (2016) point out there are several important directions in business model innovation area to explore:

- Internal and external antecedents of business model innovation;

- Micro-level, firm-level, mezzo-level and macro level factors moderating business model innovations;

- Business model innovation outcomes evaluation in particular in the financial perspective.

Business model innovation are driven by various factors and platforms might act as external factor pushing companies to innovate in business model context. Having this in mind we will explore what opportunities for business model innovations are brought by platforms.

\section{Business Model Innovation Opportunities Through Platforms}

As platforms have been around for several decades' companies are adapting their business models in platform use perspective.

The "platform business model" is used to describe companies which develop platforms for their activities. According Schweiger et al. (2016) the term is not clearly defined because of different levels of research address this phenomenon.

The business model of the platform was analyzed by several researchers aiming to identify business model innovative aspects. Kim (2015) basing on Kim (2014) and Eisenmann et al. (2008) research proposed these important elements:

- Platform providers define platform components and rules, which are followed by platform users;

- The platform providers deal with demand, supply and external sides. External side mainly refers to advertisers, who are interested in demand and supply sides. Different suppliers, content providers, producers and developers might act as supply-side parties. Demanders, consumers, and end-users might act as demand-side parties.
- The transaction between these parties are facilitated through the platform. As more transaction are happening more direct and indirect network effects are created.

As it was stated earlier business model aims to answer four key questions and companies adopt platforms in order to innovate in business model context. Having this in mind we will try to explore platforms impact in business model innovation context.

Business model concept address customer segments as important aspect as companies aims to satisfy selected segment's needs. From one hand digital platforms enable to reach any end users segment in the global market, however different type of users (segments) will use the platforms. According to EY (2016) four type of users can be distinguished:

- Platform owners. These organizations own platform and are in charge for developing and ensuring platform functioning.

- Key partners. Organizations involved in platforms activities and offering opportunities to platforms owners to extend value creation and transfer possibilities.

- Peer producers. Different organizations is contributing to platform activities with value offerings and seeking for opportunities to improve their value offerings and obtain additional revenues.

- Peer consumers. Persons or organizations are acting as end users of the platform and getting out value from the use of the platform.

Peer consumers are the typical segments companies approach in traditional business model, however peer producers and key partners also are targeted by platforms value offers. Satisfying these users' needs lead to successful platform business model implementation.

EY (2016) study in a similar manner to Kim (2015) research identify important collaboration aspects of the platforms enabling value creation:

- Analytical data and management ensuring services development and quality assurance;

- Partnership with different partners;

- Products and services aggregation and offering;

- Services solutions development and delivery;

- Customer experience management;

The value creation in platforms different from traditional approach through several perspectives. The example of such differences is provided in Table 2 .

Table 2

Value Creation Through Platforms

(Adapted from Parker at all, 2016)

\begin{tabular}{|l|l|l|}
\hline \multicolumn{1}{|c|}{$\begin{array}{c}\text { Value creation } \\
\text { aspects }\end{array}$} & Platform impact & \multicolumn{1}{c|}{ Example } \\
\hline $\begin{array}{l}\text { Reconfiguring value } \\
\text { creation to tap new } \\
\text { sources of supply. }\end{array}$ & $\begin{array}{l}\text { Platform reduce } \\
\text { barrier to enter } \\
\text { market and establish } \\
\text { new source of value } \\
\text { creation. }\end{array}$ & $\begin{array}{l}\text { New partners can } \\
\text { easily use Amazon } \\
\text { platform to offer } \\
\text { their products to } \\
\text { consumers. }\end{array}$ \\
\hline
\end{tabular}




\begin{tabular}{|c|c|c|}
\hline $\begin{array}{l}\text { Value creation } \\
\text { aspects }\end{array}$ & Platform impact & Example \\
\hline $\begin{array}{l}\text { Reconfiguring value } \\
\text { consumption by } \\
\text { enabling new forms of } \\
\text { consumer behavior. }\end{array}$ & $\begin{array}{l}\text { Value is not } \\
\text { associated only with } \\
\text { the product or } \\
\text { service, but also } \\
\text { with the experience } \\
\text { obtained through the } \\
\text { platform. }\end{array}$ & $\begin{array}{l}\text { Amazon customers } \\
\text { review helps to } \\
\text { make decision and } \\
\text { creates more trust } \\
\text { between other } \\
\text { customers. }\end{array}$ \\
\hline $\begin{array}{l}\text { Reconfiguring quality } \\
\text { control through } \\
\text { community-driven } \\
\text { curation. }\end{array}$ & $\begin{array}{l}\text { Platform users take } \\
\text { an active role in } \\
\text { content creation and } \\
\text { content curation. } \\
\text { Basing on such } \\
\text { feedback key } \\
\text { services/products of } \\
\text { the platform are } \\
\text { identified customers. }\end{array}$ & $\begin{array}{l}\text { Amazon customers' } \\
\text { rates companies } \\
\text { offering their } \\
\text { products through } \\
\text { Amazon platform. If } \\
\text { ratings of the seller } \\
\text { are low Amazon will } \\
\text { not continue } \\
\text { cooperation with } \\
\text { such partner. }\end{array}$ \\
\hline $\begin{array}{l}\text { De-linking assets from } \\
\text { value. }\end{array}$ & $\begin{array}{l}\text { The use of the asset } \\
\text { to be independently } \\
\text { traded and applied } \\
\text { to its best use. }\end{array}$ & $\begin{array}{l}\text { Opportunities to } \\
\text { rent books through } \\
\text { Amazon platform } \\
\text { when there are } \\
\text { needed instead of } \\
\text { buying them. }\end{array}$ \\
\hline Re-intermediation. & $\begin{array}{l}\text { Serving as one of } \\
\text { the key destination } \\
\text { site in accessing } \\
\text { desired services and } \\
\text { goods. }\end{array}$ & $\begin{array}{l}\text { Amazon intention } \\
\text { to become the main } \\
\text { online shopping } \\
\text { destination as } \\
\text { serving as main } \\
\text { intermediary } \\
\text { between partners } \\
\text { and customers. }\end{array}$ \\
\hline Market aggregation. & $\begin{array}{l}\text { Bringing } \\
\text { possibilities to } \\
\text { customers to access } \\
\text { different products } \\
\text { and services as one } \\
\text { stop shop". }\end{array}$ & $\begin{array}{l}\text { Amazon constantly } \\
\text { increase their } \\
\text { products } \\
\text { assortment through } \\
\text { new companies } \\
\text { acquiring and new } \\
\text { partners' attraction. }\end{array}$ \\
\hline
\end{tabular}

The platform business models aims to satisfy different needs of consumers. Oxera (2016) analysed platform case sin four European Union countries - Germany, France, Spain and Poland. Basing on case analyses the main reasons why customers and companies use platforms were identified (see Table 3).

Table 3

\section{Reasons For Using Platforms}

(Adapted From Oxera, 2016)

\begin{tabular}{|c|c|}
\hline Consumers & Companies \\
\hline \multicolumn{2}{|c|}{$\begin{array}{l}\text { Reasons for using platforms } \\
\end{array}$} \\
\hline $\begin{array}{l}\text { - } \quad \text { communication; } \\
\text { - } \text { entertainment; } \\
\text { - } \text { online marketplace; } \\
\text { - comparison; } \\
\text { - information. }\end{array}$ & $\begin{array}{l}\text { - reach a wider market; } \\
\text { - low-cost channel for gathering } \\
\text { customer feedback; } \\
\text { - platforms are much cheaper } \\
\text { than bricks and-mortar stores. }\end{array}$ \\
\hline
\end{tabular}

The platforms might have the different effect on companies' business model financial aspects. According Oxera (2016) report these financial aspects might be outlined:

- The platform impact on operating costs varies. Some companies using e-commerce platforms prefer to sell directly in order to avoid the fees charged by the platform.

- As distribution channels platforms are much cheaper than bricks and-mortar stores.

- Platforms reduce search and transaction cost.

- Online platforms reduce marketing cost.
Platforms became a challenging issues in the last years and many companies consider platforms business model as a future prospect for successful development. According D. Sneider (2016) "every organization needs a digital platform strategy... but... digital platform strategy will vary from company to company. Some companies will develop a platform business model that encompasses providers, consumers and employees to create or exchange goods, services and social interaction. Others might integrate with other organizations' digital platforms." Parker et all (2017) analysed the early attempts to apply platform business model and identifies key factors why platform business model is failing:

- Failure to optimize openness. Platforms acts as basis for ecosystem and openness ensure involvement of different players. The low involvement will not lead to network effects and this causes the business model failure.

- Failure to engage developers. Platforms are like living organism - developing according user needs through improved features and functionality. Platforms failing to stick to this "digital Darwinism" fails in the long term.

- Failure to share the surplus. The platform business model success when value is obtained by all involved parties. If companies implementing platform business model retains most of the value without sharing with the rest involved parties, the business model doesn't sustain.

- Failure launch the right side. Platforms business model is based on certain balance between different sides. According Parker et all (2017) "Sometimes at launch it's important to focus on attracting consumers over producers, sometimes it's the reverse, and sometime both sides need equal attention from the outset."

- Failure to put critical mass ahead of money. Building critical mass is important factor in platform business model development. Facebook and Google attracted large number of users offering free value and later finding the ways how to monetize platform. Companies fails in platform business model implementation if monetization of platforms overtake critical mass building.

- Failure of imagination. Platform business model requires different approach in value creation, value capture and value transfer. Some companies, such as Sony, HP or Garmin made mistakes "emphasizing products over the platform (Parker et all, 2017)". Platform business model obliges cooperation with other ecosystems actors instead of simple sell-buy relations.

\section{Conclusions}

Platform phenomenon became increasingly important and according different prognosis companies needs to rethink their business models in order to use opportunities platforms are bringing.

Digitalization is considered as a strategy how to adapt and use digital technologies instead just of just upgrading them. In this context, the clear shift in platform use is 
observed. Earlier platforms were treated as information communication technologies based infrastructure allowing successfully perform operations, However nowadays platforms became basics for ecosystems allowing to orchestrate and organize activities of many companies.

Platforms bring new opportunities for value creation, value capture, and value transfer, so companies need to innovate their business models through value orchestration or value reconfiguration, re-intermediation or disintermediation, etc. Several companies will manage successful platforms, but most of the companies will need to find out how to adopt platforms.

Platforms are often treated as a new opportunity for business model innovations, However, companies need carefully evaluate these opportunities. As platforms are gaining more market power, this brings serious considerations for companies what kind of relations with platform owners should be developed and how to compete in the market if platforms are not used.

Even if companies utilize platforms potential and decide to innovate their business model some important aspects need to be considered in order to avoid failure. Openness optimization, surplus sharing, critical mass acquisition, selection of the right side requires carefully rethink how business model innovation will be tackled.

\section{Acknowledgment}

This research is funded by ENVISION project, by the European Commission Horizon 2020 programme.

\section{References}

Accenture (2016). Five Ways to Win with Digital Platforms. https://www.accenture.com/us-en/_acnmedia/PDF29/Accenture-Five-Ways-To-Win-With-Digital-Platforms-Full-Report.pdf

Andersson Schwarz, Jonas. (2015). Platform logic: The need for an interdisciplinary approach to the platform-based economy. In IPP2016, 22-23 September 2016 [1/19]. Oxford University.

Amit, R., Zott, C. and Pearson, A. (2012). 'Creating value through business model innovation', MIT Sloan Management Review, 53.

Ballon, P. and Walravens, N. (2008). Competing platform models for mobile service delivery: the importance of gatekeeper roles. In Mobile Business, 2008. ICMB'08. 7th International Conference. IEEE: pp. $102-111$. https://doi.org/10.1109/ICMB.2008.17

BCG. Business model innovation. (2017). https://www.bcg.com/capabilities/strategy/business-model-innovation.aspx

Bouwman et al., 2008 Bouwman, Harry, Henny de Vos, \& Timber Haaker, eds. (2008). Mobile service innovation and business models. Springer Science \& Business Media. https://doi.org/10.1007/978-3-540-79238-3

Bughin J. New evidence for the power of digital platforms. (2017) MsKinsey Quarterly, https://www.mckinsey.com/businessfunctions/digital-mckinsey/our-insights/new-evidence-for-the-power-of-digital-platforms.

Cameron, B. G., \& Crawley, E. F. (2014). Crafting platform strategy based on anticipated benefits and costs. In Advances in Product Family and Product Platform Design (pp. 49-70). Springer New York. https://doi.org/10.1007/978-1-46147937-6_2

Ceccagnoli, M., Forman, C., Huang, P., \& Wu, D. (2011). 'Co-creation of value in a platform ecosystem: The case of enterprise software', MIS Quarterly, 36(1), 263-290.

Chesbrough, H. (2010). Business model innovation: opportunities and barriers. Long range planning, 43(2), 354-363. https://doi.org/10.1016/j.lrp.2009.07.010

Cooke, P. (2012). 'From clusters to platform policies in regional development'. European Planning Studies, 20(8), 14151424. https://doi.org/10.1080/09654313.2012.680741

Cusumano, M. A. (2008). The changing software business: Moving from products to services. Computer, 41(1). https://doi.org/10.1109/MC.2008.29

Cusumano, M. A. (2012). Platforms versus products: Observations from the literature and history. In History and Strategy (pp. 35-67). Emerald Group Publishing Limited. https://doi.org/10.1108/S0742-3322(2012)0000029006

Digital Mobility Platforms and Ecosystems State of the Art Report (edited by Anne Faber, Florian Matthes, Felix Michel). 2016.

Ecosystems. New York, Harper Business, 297p Osterwalder and Pigneur (2009), Osterwalder, Alexander, \& Yves Pigneur. (2010). Business model generation: a handbook for visionaries, game changers, and challengers. John Wiley \& Sons.

Eisenmann, T. R., Parker, G., \& Van Alstyne, M. W. (2008). Opening platforms: how, when and why?. Harvard Business School Entrepreneurial Management Working Paper No. 09-030. Available at : http://ssrn.com/abstract=1264012 https://doi.org/10.2139/ssrn.1264012

Eisenmann, T., Parker, G. and Van Alstyne, M. (2011). 'Platform envelopment'. Strategic Management Journal, 32(12), 1270-1285. https://doi.org/10.1002/smj.935

ENVISION project presentation. European SMEs Congress, Katowice. 2017.

European Commission. (2016). Communication from the Commission to the European Parliament, the Council, the European Economic and Social Committee and the Committee of the Regions - Online Platforms and the Digital Single 
Market Opportunities and Challenges for Europe http://eur-lex.europa.eu/legal-content/EN/TXT/PDF/?uri=CELEX :52016DC0288\&from=EN

Evans, C. Peter and Annabelle Gawer, (2016). The Rise of the Platform Enterprise: A Global Survey. New York: The Center for Global Enterprise

EY. If sustainable value is created when all stakeholders benefit, how will you realize your formula for success? (2016). http://www.ey.com/Publication/vwLUAssets/ey-progressions-bioPharma-4-0-platform-models-to-capturevalue/\$FILE/ey-progressions-bioPharma-4-0-platform-models-to-capture-value.pdf

Foss, N. J., \& Saebi, T. (2017). Fifteen years of research on business model innovation: How far have we come, and where should we go?. Journal of Management, 43(1), 200-227. https://doi.org/10.1177/0149206316675927

Gartner (2016). Every Organization Needs a Digital Platform Strategy . https://www.gartner.com/smarterwithgartner/everyorganization-needs-a-digital-platform-strategy/

Gawer, A., \& Cusumano, M. A. (2014). Industry platforms and ecosystem innovation. Journal of Product Innovation Management, 31(3), 417-433. https://doi.org/10.1111/jpim.12105

Kenney, M., \& Zysman, J. (2016). The rise of the platform economy. Issues in Science and Technology, $32(3), 61$.

Kim J. The Platform Business Model and Strategy: A Dynamic Analysis of the Value Chain and Platform Business (2015). $\mathrm{PhD}$ thesis. University of Manchester.

Kim, J. (2014). Platform business and network strategy. STI Policy Review, 5(1), 57-74.)

McAfee Andrew and Erik Brynjolfsson, (2017). Machine, Platform, Crowd: Harnessing Our Digital Future. New York: W. W. Norton \& Company.

MIT Platform Strategy Summit, 2017. Report.

Moore, J. F. 1996. The Death of Competition: Leadership \& Strategy in the Age of Business

Oxera (2016). Benefits of online platforms. https://www.oxera.com/getmedia/84df70f3-8fe0-4ad1-b4bad235ee50cb30/The-benefits-of-online-platforms-main-findings-(October-2015).pdf.aspx?ext=.pdf

Parker, G. G., Van Alstyne, M. W., \& Choudary, S. P. (2016). Platform revolution: How networked markets are transforming the economy--and how to make them work for you. WW Norton \& Company.

Schweiger, A., Nagel, J., Bohm, M., \& Krcmar, H. (2016). Platform Business Models. Digital Mobility Platforms and Ecosystems, 66.

Sneider D. Every Organization Needs a Digital Platform Strategy. (2016) https://www.gartner.com/smarterwithgartner/ every -organization-needs-a-digital-platform-strategy/

Tauscher, K., \& Laudien, S. M. (2017). Understanding platform business models: A mixed methods study of marketplaces. European Management Journal. https://doi.org/10.1016/j.emj.2017.06.005

World Economic Forum (2016). Davos 2016 - A New Platform for the Digital Economy. On YouTube. Retireved 12 May 2017, from https://www.youtube.com/watch?v=-pFRIlgEdl0.

Zysman, J., \& Kenney, M. (2016). The Next Phase in the Digital Revolution: Platforms, Abundant Computing, Growth and Employment. The Research Institute of the Finnish Economy.

The article has been reviewed.

Received in October, 2017; accepted in December, 2017. 